\title{
Plasma biochemical and minerals parameters in Arbia goats of a semi-arid region of North-Eastern Algeria during different stages of production
}

\author{
Sofia Amel Allaoua ${ }^{1}$, and Djahida Mahdi ${ }^{1,2 *}$ \\ ${ }^{1}$ Department of Nature and Life Sciences, Faculty of Exact Sciences and Nature and Life Sciences, Larbi Ben \\ M'hidi Oum El Bouaghi University, Oum EL Bouaghi, Algeria \\ ${ }^{2}$ Laboratory of Animal Ecophysiology, Department of Biology, Faculty of Sciences, University Badji Mokhtar- \\ Annaba, Annaba, Algeria
}

\begin{abstract}
ALLAOUA, S. A., D. MAHDI: Plasma biochemical and minerals parameters in Arbia goats of a semi-arid region of North-Eastern Algeria during different stages of production. Vet. arhiv 88, 643-660, 2018.
\end{abstract}

\section{ABSTRACT}

The aim of this study was to investigate the variations in concentrations of blood parameters during different stages of production in Arbia goats, reared traditionally in semi-arid regions of North-Eastern Algeria. Ten does (12 \pm 0 months old) were chosen from one farm. Blood was collected once from each doe before gestation, at $6.87 \pm 4.61$ days prepartum (late gestation), in the $3^{\text {rd }}$ (early lactation), $8^{\text {th }}$ (mid lactation), $12^{\text {th }}$ (late lactation), and $16^{\text {th }}$ weeks of lactation (end lactation), and during the $2^{\text {nd }}$ week of the dry period. Plasma glucose (Glu), cholesterol (Chol), urea, creatinine (Creat), triglycerides (TG), total protein (TP), albumin (Alb), globulin (Glb), alanine aminotransferase (ALT), aspartate aminotransferase (AST), Ca, Pi, Fe, Mg, Na, K, and $\mathrm{Cl}$ were measured. Plasma levels of Chol were not significantly affected by the productive stage of the Arbia goats. During late gestation, TG and Creat recorded the highest levels. Compared to late gestation, urea and $\mathrm{K}$ increased, and AST activity decreased significantly in late lactation; Glu, Alb, TP, and urea increased significantly at the end of lactation and Fe increased during mid lactation. During lactation, plasma levels of Pi, $\mathrm{Mg}, \mathrm{Na}$, and $\mathrm{K}$ did not change, but Glu and $\mathrm{Fe}$ decreased significantly at mid lactation, $\mathrm{TG}$ decreased, and Creat increased at early lactation; TP, Glb, and AST activity decreased in late lactation, while ALT, urea, Ca increased, but $\mathrm{Cl}$ decreased during end lactation. Compared to the dry period, Glu, Alb, ALT, AST, Na, and K decreased, Creat, and Glb increased significantly before gestation; TG and Creat increased, and Alb and AST activity decreased significantly during late gestation. In conclusion, determination of blood parameters is necessary for better control of the health and nutrition of Arbia goats.

Key words: plasma blood parameters; physiological stages of production; Arbia goats; Semi-arid; Algeria

\footnotetext{
*Corresponding author:

Assoc. Prof. Djahida Mahdi, PhD in Animal Biology, Department of Nature and Life Sciences, Faculty of Exact Sciences and Nature and Life Sciences, Larbi Ben M'hidi Oum EL Bouaghi University, BP 358 Oum El Bouaghi, Route de Constantine Oum El Bouaghi 04000, Algeria, Phone: +213 6660490 59; E-mail: djahidamahdi@yahoo.com
} 
S. A. Allaoua and D. Mahdi: Effect of physiological status on levels of blood parameters in female Arbia goats

\section{Introduction}

In the last few years, farmers have been more interested in rearing and breeding goats in Algeria as a result of the high demand for their products by consumers. The nutritional importance of goat's milk is well known (PARK et al., 2007; HELMUT and GREGOR, 2012; PARK, 2012), but there is also importance in their kids' meat (WEBB et al., 2005; TOMOVIĆ et al., 2016). Consequently, the number of goats has increased to reach 4.9 million out of 35 million heads of all types of ruminants in Algeria, according to the Food and Agriculture Organisation of the United Nations (FAOSTAT, 2017). Goats are reared mainly in mountainous areas, but the largest number is distributed in the steppe and Sub-Saharan zones of Algeria (MOUSTARIA, 2008). The Arbia goat is one of the most popular breeds for milk and meat production. Therefore it is important to conserve and control the health of the goats for increasing animal production. It is evident that the blood levels of various blood parameters can be used as criteria for diagnosis and prognosis of metabolic diseases, as well as for assessment of nutritional status (BALIKCI et al., 2007; KARAPEHLIVAN et al., 2007; TANRITANIR et al., 2009; BAGNICKA et al., 2014). However, in the last few years, many researchers have shown that the blood parameters of small ruminants are influenced by many factors such as age (MBASSA and POULSEN, 1991; ANTUNOVIC et al., 2017), geographical locations with different climates, gender, season, breed (AZAB and ABDEL-MAKSOUD, 1999; ANWAR et al., 2012; PICCIONE et al., 2012; DONIA et al., 2014; BAGNICKA et al., 2014; RIBEIRO et al., 2016), and the physiological stages of production (AZAB and ABDEL-MAKSOUD, 1999; IRIADAM, 2007; PICCIONE et al., 2011; DONIA et al., 2014; SADJADIAN et al., 2013). Several studies showed great variations in the levels of blood parameters between breeds of goats during the periods of pregnancy, parturition, and lactation (TANRITANIR et al., 2009; IRIADAM, 2007; WAZIRI et al., 2010; DARWESH et al., 2013). These three physiological stages of production are known to cause metabolic stress.

The aim of this study was to investigate the variations in some biochemical and mineral blood parameters during different stages of production in Arbia goats, reared traditionally in semi-arid zones of North-Eastern Algeria.

\section{Materials and methods}

Experimental site and animals. The experiment started in the summer (July) of 2013 at the Maameri farm in Touzeline, $20 \mathrm{~km}$ from the Oum El Bouaghi province (35'52' 39' $\mathrm{N}, 7^{\circ} 6^{\prime} 49^{\prime \prime} \mathrm{E}$ ) at an altitude of $902 \mathrm{~m}$. This area of Algeria is considered as a semi-arid zone, and its climate is characterized by hot summers and cold dry winters. Ten gravid and clinically healthy Arbia does, with a mean body weight of $23.74 \pm 1.28 \mathrm{~kg}$ and a mean age of $12 \pm 0$ months, were chosen from a herd of 45 animals. The Arbia goat is the predominant breed in Algeria, and they are used for their meat and milk. During the 
trial, all the animals were reared in a traditional production system and kept under natural photoperiod and temperatures. The animals were fed by natural grazing for the whole day, while in the evening they were fed straw or hay according to what was available on the farm. In winter and during extreme weather conditions, the animals were kept indoors, and once a day were given a mixture (500-1000 g/goat/day) of barley either as grain or crushed $(35 \%)$ and wheat bran $(65 \%)$; barley was replaced by flour in the grain ( $500 \mathrm{~g} /$ goat/day) when it was not available. In addition to the food mixture, $8-9 \mathrm{~kg} / \mathrm{day} /$ ten goats high quality hay was also given, salt licks and water ad libitum. The duration of pregnancy and lactation in these animals were $154.37 \pm 3.81$ and $122.38 \pm 8.61$ days respectively, and lactation in all goats began during the winter season (in December). The goats were in their first lactation. The experimental procedures were carried out according to the National Institute of Health Guidelines for Animal Care and were approved by the Ethics Committee of our Institution.

Blood sampling and analyses. Blood was collected once from each doe before gestation, at $6.87 \pm 4.61$ days prepartum (Late gestation), in the $3^{\text {rd }}$ (early lactation), $8^{\text {th }}$ (mid lactation), $12^{\text {th }}$ (late lactation), and $16^{\text {th }}$ weeks of lactation (end lactation), and during the $2^{\text {nd }}$ week of the dry period. Blood samples were collected into $10 \mathrm{~mL}$ heparinized tubes from the jugular vein, always in the morning (7a.m.) before feeding. They were immediately centrifuged for $15 \mathrm{~min}$ at speeds of $3000 \mathrm{rpm}$. Plasma was harvested and stored at $-20{ }^{\circ} \mathrm{C}$ until analysis of glucose, cholesterol, triglycerides, total protein, albumin, urea, creatinine, alanine aminotransferase (ALT), aspartate aminotransferase $(\mathrm{AST})$, calcium $(\mathrm{Ca})$, inorganic phosphorus $(\mathrm{Pi})$, iron $(\mathrm{Fe})$, and magnesium $(\mathrm{Mg})$, by using a Siemens, ADVIA 1800 Chemistry System (Germany, 2007), and corresponding commercially available kits for each plasma parameter studied. Sodium $(\mathrm{Na})$, potassium $(\mathrm{K})$, and chloride $(\mathrm{Cl})$ were assayed by The Dimension RxL Max Integrated Chemistry System (Germany, 2007). Globulin content was calculated as the difference between total protein and albumin concentrations.

Statistical analysis. The results were analysed by ANOVA (StatisticaVersion 5.1, StatSoft France, 1997). Multiple comparisons were made using the test of LSD for postANOVA multiple comparisons $(\mathrm{P}<0.05)$. All data are presented as means $\pm \mathrm{SD}$ (standard deviation).

\section{Results}

The results show that the productive stage of Arbia goats did not have a significant effect on plasma levels of cholesterol (Table 1), but the levels of the remaining blood parameters showed different significant variations (Table 1 to Table 4 ). The mean plasma concentrations of glucose showed non-significant changes during the lactation periods compared to the values before and in late gestation, and decreased significantly during 
mid lactation compared to early lactation $(\mathrm{P}<0.003)$, and the dry period $(\mathrm{P}<0.002)$, and in this later period, its plasma level was significantly higher $(\mathrm{P}<0.01)$ compared to before gestation (Table1). However, glucose concentrations did not change significantly between the dry and late gestation periods. Differences in the cholesterol plasma levels were not significant during any of the experimental periods of reproduction studied (Table 1). The plasma triglyceride concentration (Table 1) increased significantly $(\mathrm{P}<0.02)$ from before pregnancy to late gestation. Thereafter, it decreased significantly at all periods of lactation as well as during the dry period when compared to late pregnancy. During the dry period, triglyceride levels were also significantly higher than those determined during early and at the end of lactation $(\mathrm{P}<0.02)$. The lowest triglyceride concentrations were observed at 3 weeks $(0.16 \mathrm{mmol} / \mathrm{L} \pm 0.05)$, and they were significantly lower than those recorded at 12 weeks of lactation $(\mathrm{P}<0.05)$, when they reached levels similar to those measured in non-pregnant goats. The highest level of triglyceride was recorded during late gestation. Plasma albumin (Table 1) did not show any significant changes until the goats reached the end of lactation and the dry period, when albumin values showed the highest level, but the values determined in the dry period were non-significant compared to mid and early lactation. The values of albumin during late lactation were significantly lower compared to the end of lactation $(\mathrm{P}<0.05)$, and the dry period $(\mathrm{P}<0.0003)$.

Table 1. Peripheral plasma concentrations of glucose, cholesterol, triglycerides and albumin in Arbia does at different stages of production (Mean $\pm \mathrm{SD}, \mathrm{n}=10)$

\begin{tabular}{|l|c|c|c|c|}
\hline \multirow{2}{*}{$\begin{array}{l}\text { Stage of } \\
\text { production }\end{array}$} & \multicolumn{4}{|c|}{ Blood metabolites } \\
\cline { 2 - 5 } & $\begin{array}{c}\text { Glucose } \\
(\mathrm{mmol} / \mathrm{L})\end{array}$ & $\begin{array}{c}\text { Cholesterol } \\
(\mathrm{mmol} / \mathrm{L})\end{array}$ & $\begin{array}{c}\text { Triglycerides } \\
(\mathrm{mmol} / \mathrm{L})\end{array}$ & $\begin{array}{c}\text { Albumin } \\
(\mathrm{g} / \mathrm{L})\end{array}$ \\
\hline Before gestation & $3.08 \pm 0.52^{\text {ad }}$ & $1.85 \pm 0.34$ & $0.40 \pm 0.11^{\mathrm{a}}$ & $33.29 \pm 3.44^{\mathrm{a}}$ \\
\hline Late gestation & $3.45 \pm 0.58^{\text {acd }}$ & $2.06 \pm 0.23$ & $0.54 \pm 0.21^{\mathrm{b}}$ & $32.45 \pm 1.56^{\mathrm{a}}$ \\
\hline Early lactation & $3.54 \pm 0.26^{\text {df }}$ & $1.87 \pm 0.22$ & $0.16 \pm 0.05^{\mathrm{c}}$ & $33.26 \pm 2.16^{\text {ad }}$ \\
\hline Mid lactation & $2.92 \pm 0.56^{\text {ae }}$ & $1.91 \pm 0.32$ & $0.24 \pm 0.06^{\text {cef }}$ & $36.00 \pm 6.15^{\text {ab }}$ \\
\hline Late lactation & $3.45 \pm 0.33^{\text {deg }}$ & $1.92 \pm 0.30$ & $0.28 \pm 0.05^{\text {aedg }}$ & $33.09 \pm 4.78^{\text {a }}$ \\
\hline End of lactation & $3.45 \pm 0.62^{\text {edf }}$ & $1.92 \pm 0.27$ & $0.19 \pm 0.08^{\text {cfg }}$ & $37.27 \pm 3.13^{\text {bcd }}$ \\
\hline Dry period & $3.84 \pm 0.78^{\text {bcfg }}$ & $2.03 \pm 0.32$ & $0.32 \pm 0.12^{\text {ae }}$ & $41.20 \pm 5.07^{\mathrm{c}}$ \\
\hline
\end{tabular}

SD - Standard deviation. Means in the same column with different superscrips differ significantly.

Total protein (Table 2$)$ increased significantly $(\mathrm{P}<0.05)$ during the end of lactation compared to before pregnancy, late pregnancy, and late lactation, and a significant increase was found at early lactation compared to before gestation and in the dry period. During lactation total protein decreased significantly during late lactation compared to early, mid and end lactation, and their values were similar to those recorded during the dry period, before gestation, and in late gestation. A significant increase in the plasma level of globulins (Table 2) was recorded during early and end lactation, compared to 
that noted before gestation $(\mathrm{P}<0.01)$, then it decreased sharply during the dry period $(\mathrm{P}<0.002)$. Urea (Table 2$)$ did not show any significant changes from the period before pregnancy until the goats reached the end of lactation, where it reached a peak level equal to $7.59 \pm 1.96 \mathrm{mmol} / \mathrm{L}$, then it decreased significantly $(\mathrm{P}<0.01)$ at week 2 of the dry period to a level similar to that seen before gestation, and at 12 weeks of lactation. The lowest level for urea was observed at late gestation, and it was significantly lower than at $12(\mathrm{P}<0.05)$, and $16(\mathrm{P}<0.001)$ weeks of lactation. The values of urea at the end of lactation were significantly higher than in early and mid lactation $(\mathrm{P}<0.01)$. As is obvious from the results, the highest level of creatinine (Table 2) was registered at late gestation compared to all the studied periods. A significant increase in creatinine at early lactation was also seen compared to late lactation $(\mathrm{P}<0.01)$, end lactation $(\mathrm{P}<0.05)$ and to the dry period $(\mathrm{P}<0.00002)$. However, creatinine did not change significantly before pregnancy compared to different stages of lactation.

Table 2. Peripheral plasma concentrations of total protein, globulin, urea and creatinine in Arbia does at different stages of production (Mean $\pm \mathrm{SD}, \mathrm{n}=10$ )

\begin{tabular}{|l|c|c|c|c|}
\hline \multirow{2}{*}{$\begin{array}{l}\text { Stage of } \\
\text { production }\end{array}$} & $\begin{array}{c}\text { Total protein } \\
(\mathrm{g} / \mathrm{L})\end{array}$ & $\begin{array}{c}\text { Globulin } \\
(\mathrm{g} / \mathrm{L})\end{array}$ & $\begin{array}{c}\text { Urea } \\
(\mathrm{mmol} / \mathrm{L})\end{array}$ & $\begin{array}{c}\text { Creatinine } \\
(\mathrm{mg} / \mathrm{L})\end{array}$ \\
\cline { 2 - 5 } & $66.00 \pm 5.26^{\mathrm{a}}$ & $32.70 \pm 3.24^{\mathrm{a}}$ & $6.05 \pm 0.67^{\mathrm{ac}}$ & $5.45 \pm 0.72^{\text {ae }}$ \\
\hline Before gestation & $68.10 \pm 2.79^{\mathrm{abc}}$ & $35.66 \pm 3.15^{\text {ad }}$ & $4.68 \pm 1.42^{\mathrm{a}}$ & $8.17 \pm 0.71^{\mathrm{b}}$ \\
\hline Late gestation & $73.25 \pm 2.05^{\text {bcd }}$ & $39.99 \pm 3.45^{\text {bdf }}$ & $5.59 \pm 1.5^{\text {ac }}$ & $6.22 \pm 0.66^{\text {da }}$ \\
\hline Early lactation & $73.00 \pm 8.12^{\text {cd }}$ & $36.99 \pm 8.35^{\text {aef }}$ & $5.43 \pm 1.16^{\text {ac }}$ & $5.85 \pm 1.42^{\text {dae }}$ \\
\hline Mid lactation & $67.30 \pm 6.34^{\mathrm{a}}$ & $35.15 \pm 6.17^{\mathrm{a}}$ & $6.57 \pm 1.12^{\text {cdf }}$ & $5.00 \pm 1.17^{\text {ce }}$ \\
\hline Late lactation & $77.00 \pm 2.72^{\mathrm{d}}$ & $39.72 \pm 1.90^{\text {bde }}$ & $7.59 \pm 1.96^{\text {bd }}$ & $5.30 \pm 0.42^{\mathrm{e}}$ \\
\hline End of lactation & $65.50 \pm 6.63^{\mathrm{a}}$ & $24.29 \pm 4.40^{\mathrm{c}}$ & $5.20 \pm 2.14^{\text {af }}$ & $4.11 \pm 0.66^{\mathrm{c}}$ \\
\hline Dry period & & &
\end{tabular}

$\mathrm{SD}$ - Standard deviation. Means in the same column with different different superscrips differ significantly

The activity of AST (Table 3) was highest during the dry period, and in this later period, it was significantly higher than before $(\mathrm{P}<0.001)$, in late gestation $(\mathrm{P}<0.01)$, and during lactation $(\mathrm{P}<0.05)$, but no significant changes were recorded between the other periods of study except for late lactation. During late lactation, AST activity decreased significantly compared to the end of lactation $(\mathrm{P}<0.005)$, late gestation $(\mathrm{P}<0.05)$, early lactation $(\mathrm{P}<0.02)$. The highest value of ALT activity (Table 3 ) was measured during the dry period, at the end of lactation and before gestation. But during the dry period ALT activity was non-significantly higher than at the end of lactation $(\mathrm{P}>0.05)$. ALT activity during the end of lactation, before and late gestation did not show significant differences. 
S. A. Allaoua and D. Mahdi: Effect of physiological status on levels of blood parameters in female Arbia goats

Table 3. Peripheral plasma concentrations of AST, ALT, CA and Pi in Arbia does at different stages of production (Mean $\pm \mathrm{SD}, \mathrm{n}=10$ )

\begin{tabular}{|l|c|c|c|c|}
\hline \multirow{2}{*}{$\begin{array}{l}\text { Stage of } \\
\text { production }\end{array}$} & \begin{tabular}{c}
$\mid 4$ \\
AST \\
\cline { 2 - 5 }
\end{tabular} & $\begin{array}{c}\text { ALT } \\
(\mathrm{U} / \mathrm{L})\end{array}$ & $\begin{array}{c}\text { Ca } \\
(\mathrm{mmol} / \mathrm{L})\end{array}$ & $\begin{array}{c}\text { Pi } \\
(\mathrm{mmol} / \mathrm{L})\end{array}$ \\
\hline Before gestation & $79.50 \pm 10^{\mathrm{ab}}$ & $19.75 \pm 3.49^{\mathrm{abc}}$ & $2.24 \pm 0.28^{\mathrm{a}}$ & $1.25 \pm 0.34^{\mathrm{a}}$ \\
\hline Late gestation & $84.62 \pm 17.95^{\mathrm{a}}$ & $18.00 \pm 3.66^{\mathrm{ab}}$ & $2.22 \pm 0.07^{\mathrm{a}}$ & $1.63 \pm 0.55^{\mathrm{ab}}$ \\
\hline Early lactation & $87.37 \pm 17.61^{\mathrm{a}}$ & $15.37 \pm 3.54^{\mathrm{a}}$ & $2.21 \pm 0.10^{\mathrm{a}}$ & $1.60 \pm 0.64^{\mathrm{ab}}$ \\
\hline Mid lactation & $72.37 \pm 10.96^{\mathrm{ac}}$ & $15.25 \pm 3.65^{\mathrm{a}}$ & $2.03 \pm 0.28^{\mathrm{a}}$ & $1.64 \pm 0.65^{\mathrm{ab}}$ \\
\hline Late lactation & $69.83 \pm 18.37^{\mathrm{bc}}$ & $14.5 \pm 7.8^{\mathrm{a}}$ & $2.21 \pm 0.27^{\mathrm{a}}$ & $1.99 \pm 0.66^{\mathrm{b}}$ \\
\hline End of lactation & $91.75 \pm 19.96^{\mathrm{a}}$ & $21.25 \pm 9.51^{\mathrm{bc}}$ & $2.54 \pm 0.14^{\mathrm{b}}$ & $1.89 \pm 0.61^{\mathrm{bc}}$ \\
\hline Dry period & $115.37 \pm 37.3^{\mathrm{d}}$ & $23.12 \pm 3.97^{\mathrm{c}}$ & $2.05 \pm 0.25^{\mathrm{a}}$ & $1.40 \pm 0.47^{\mathrm{ac}}$ \\
\hline
\end{tabular}

SD - Standard deviation. Means in the same column with different superscrips differ significantly.

Variations of mineral concentrations in the plasma of Arbia goats, depending on the stage of production, are shown in Table 3 and Table 4. Plasma calcium levels increased significantly $(\mathrm{P}<0.01)$ during end lactation compared to other stages of reproduction. However, they did not differ significantly between the other periods (Table 3). Pi concentration did not show significant changes between stages of lactation, while it increased during late lactation and differed significantly from before gestation and the dry period. Pi levels also showed non-significant changes before, in late gestation and in early lactation.

Table 4. Peripheral plasma concentrations of $\mathrm{Na}, \mathrm{K}, \mathrm{Cl}, \mathrm{Mg}$ and $\mathrm{Fe}$ in Arbia does at different stages of production (Mean $\pm \mathrm{SD}, \mathrm{n}=10)$

\begin{tabular}{|c|c|c|c|c|c|}
\hline \multirow[b]{2}{*}{$\begin{array}{l}\text { Stage of } \\
\text { production }\end{array}$} & \multicolumn{5}{|c|}{ Blood metabolites } \\
\hline & $\begin{array}{c}\mathrm{Na} \\
(\mathrm{mmol} / \mathrm{L})\end{array}$ & $\begin{array}{c}\mathrm{K} \\
(\mathrm{mmol} / \mathrm{L})\end{array}$ & $\begin{array}{c}\mathrm{Cl} \\
(\mathrm{mmol} / \mathrm{L})\end{array}$ & $\begin{array}{c}\mathrm{Mg} \\
(\mathrm{mmol} / \mathrm{L})\end{array}$ & $\begin{array}{c}\mathrm{Fe} \\
(\mu \mathrm{mol} / \mathrm{L})\end{array}$ \\
\hline $\begin{array}{l}\text { Before } \\
\text { gestation }\end{array}$ & $137.91 \pm 2.07^{\mathrm{a}}$ & $3.86 \pm 0.35^{\mathrm{a}}$ & $\begin{array}{c}108.48 \pm \\
2.71^{\text {ac }}\end{array}$ & $0.90 \pm 0.08^{a}$ & $18.85 \pm 2.31^{\mathrm{a}}$ \\
\hline Late gestation & $148.75 \pm 1.16^{\mathrm{b}}$ & $4.13 \pm 0.55^{\mathrm{ab}}$ & $110.50 \pm 1.6^{\mathrm{ac}}$ & $1.05 \pm 0.07^{\mathrm{ac}}$ & $19.85 \pm 9.58^{\mathrm{a}}$ \\
\hline Early lactation & $147.75 \pm 3.32^{b}$ & $4.32 \pm 0.45^{\mathrm{bc}}$ & $111.12 \pm 2.29^{\mathrm{a}}$ & $1.05 \pm 0.04^{\mathrm{bc}}$ & $23.26 \pm 4.47^{\mathrm{a}}$ \\
\hline Mid lactation & $145.62 \pm 8.19^{b}$ & $4.32 \pm 0.38^{\mathrm{bc}}$ & $109.62 \pm 4.17^{\mathrm{ac}}$ & $0.97 \pm 0.27^{\mathrm{ac}}$ & $13.00 \pm 2.47^{\mathrm{b}}$ \\
\hline Late lactation & $146.00 \pm 4.40^{\mathrm{b}}$ & $4.57 \pm 0.3^{\mathrm{c}}$ & $110.12 \pm 3.13^{\mathrm{ac}}$ & $1.06 \pm 0.07^{\mathrm{bc}}$ & $19.96 \pm 3.05^{\mathrm{a}}$ \\
\hline End of lactation & $148.75 \pm 2.37^{b}$ & $4.50 \pm 0.18^{\mathrm{bc}}$ & $108.12 \pm 1.88^{c}$ & $1.07 \pm 0.13^{\mathrm{bc}}$ & $21.58 \pm 3.88^{\mathrm{a}}$ \\
\hline Dry period & $146.5 \pm 5.26^{\mathrm{b}}$ & $4.35 \pm 0.39^{\mathrm{bc}}$ & $109.62 \pm 2.82^{\mathrm{ac}}$ & $0.92 \pm 0.18^{\mathrm{ac}}$ & $18.51 \pm 5.61^{\mathrm{a}}$ \\
\hline
\end{tabular}

SD - standard deviation. Means in the same column with different superscrips differ significantly. 
$\mathrm{Na}$ and K plasma concentrations followed the same pattern (Table 4), they did not change significantly from late gestation to the dry period, but this later period showed higher $\mathrm{Na}(\mathrm{P}<0.001)$ and $\mathrm{K}(\mathrm{P}<0.05)$ values than those determined before gestation. On the other hand, the mean level of chloride plasma decreased significantly during the end of lactation compared to early lactation $(\mathrm{P}<0.05)$, but it did not record any significant variation between the other studied periods (Table 4). Mean plasma levels of magnesium did not show any significant difference during lactation, the dry period, and late gestation, but were found to be significantly lower $(\mathrm{P}<0.05)$ before gestation compared to early, late and the end of lactation (Table 4). Fe concentrations in plasma (Table 4) did not show any significant variations between all the studied periods, except for the mid lactation period, where the mean value of Fe was found to drop significantly $(\mathrm{P}<0.035)$.

\section{Discussion}

Several studies have shown great variations in the levels of blood parameters between breeds of goats during different stages of production. The results of the present research on Arbia goats reared traditionally in semi-arid zones of North-Eastern Algeria indicated that all investigated plasma blood parameters levels showed different variations, but plasma cholesterol levels did not change significantly during the study. $\mathrm{Pi}, \mathrm{Na}$, and $\mathrm{Mg}$ did not change significantly between stages of lactation. Non-significant variations in glucose, cholesterol, ALT, and $\mathrm{Cl}$ levels were also seen between different stages of lactation and before gestation, while plasma levels of total protein, globulin, albumin, were not affected by the late gestation period. What was particularly interesting was that during lactation glucose decreased significantly only at mid lactation compared to early lactation, but its levels showed non-significant changes during the lactation periods compared to before and late gestation. Similarly, BEDO et al. (1997) reported a decrease in glucose at mid lactation in ewes. In contrast, DARWESH et al. (2013) found an increase in glucose at 6 weeks of lactation (early lactation) as compared to mid and late stages of lactation in Black does. However, a decrease in blood glucose concentrations during the first 2 weeks of lactation then a gradual increase after day 13 postpartum until 45 days, was seen in Saanen dairy goats (SADJADIAN et al., 2013). The increase in plasma glucose during early lactation was not significant compared to before and late gestation. Similar results were detected by MANAT et al. (2016) in Surti goats, but SADJADIAN et al. (2013) recorded plasma glucose levels to be higher during lactation than in late pregnancy in Saanen does. In this study, the decrease in glucose levels at mid lactation compared to the dry period appeared to be related to high energy demands due to lactation. Meanwhile, there were non-significant changes at 3 weeks postpartum as compared to the dry period. In contrast, a study on Tuj ewes showed that serum glucose concentrations in ewes on days 1 and 30 of lactation were higher than those at 3 weeks after drying (KARAPEHLIVAN 
et al., 2007). Thus, it should be considered that the glucose level has strong homeostatic regulation in Arbia goats, and its variation in the plasma is a feature of this breed of goat. Moreover, the glucose values obtained in this study were similar to the reference range reported by KANEKO et al. (2008), which indicated that the animals were in a positive energy balance.

In this study, the total cholesterol plasma values were not significantly influenced by the physiological status of Arbia goats as was also found by ANTUNOVIĆ et al. (2011a; $2011 b$ ) in ewes. However, in previous studies, the cholesterol level was higher in goats and sheep during late pregnancy (NAZIFI et al., 2002; BALIKCI et al., 2007; WAZIRI et al., 2010; IRIADAM, 2007), it decreased during the last 2 weeks of pregnancy, at 10 days post-partum (SKOTNICKA et al., 2011), at 7 days (AMER et al., 1999), and 21 days (IRIADAM, 2007); at 2 weeks of lactation (SADJADIAN et al., 2013), and it was higher in lactating than pregnant non-lactating does and even peaked on day 42 postpartum (SADJADIAN et al., 2013), or on $7^{\text {th }}$ day after parturition (WAZIRI et al., 2010). From our results we can deduce that the growing requirement for energy during lactation is well equilibrated.

Triglyceride plasma concentrations were higher in late pregnancy (highest values) than in non-pregnant Arbia goats. These results are in agreement with those determined in goats (SKOTNICKA et al., 2011), and in sheep (ANTUNOVIC et al., 2011a; NAZIFI et al., 2002). In these two species, the elevated level of triglyceride during late gestation was due to the reduced insulin-mediated inhibition of lipolysis, and therefore enhancement of lipolysis in the liver and adipose tissue. On the other hand, glucocorticoides, catecholamines and glucagon hormones increased to prepare the animal for lactation (VAZQUEZ-ANON et al., 1994; GRUM et al., 1996), or there was an increase in verylow-density lipoprotein (THARWAT et al., 2013). The decrease in triglyceride during lactation in the present study was also found in Surti goats from 14 to 45 days of lactation as compared to non-pregnant goats (MANAT et al., 2016). The results of this study showed no significant changes in triglyceride levels between early, mid, and the end of lactation, but they were higher in late lactation than early lactation. In contrast to our findings, other researchers reported non-significant changes between early, mid and late lactation in black goat (DARWESH et al., 2013), and in Valfortorina goats (CASAMASSIMA et al., 2007), whereas triglyceride tended to increase as Montefalcone goats advanced in stages of lactation (CASAMASSIMA et al., 2007). The decrease in triglyceride levels could be the result of the use of fat reserve mobilization for milk production (WANGSHENG et al., 2014). The decrease in triglycerides during early lactation found in the present study could not be an indicator of negative energy because during this period glucose did not decrease compared to before pregnancy, which means the animals were in a positive energy status. 
The present study revealed a non-significant difference in albumin levels during the whole study until the end of lactation and the dry period. Similarly, non-significant changes in albumin levels during post-partum compared to before gestation were found in goats (MANAT et al., 2016). BALIKCI et al. (2007) found also that albumin levels in sheep did not differ significantly between late gestation and early lactation. Contrary to our results, concentrations of total protein and albumin in the blood of goats in the prepartum period were lower than the postpartum period and then decreased dramatically at the end of lactation in SADJADIAN et al., 2013. Similarly to our findings, the increase in plasma of albumin was noticed during the dry period and at the end of lactation by PICCIONE et al. (2009). However, KARAPEHLIVAN et al. (2007) found a decrease in albumin during the dry period compared to that at the onset of lactation in ewes, and BAGNICKA et al. (2014) reported a decrease only at the end of lactation in goats. During late pregnancy, the albumin level was in the range of the reference values (KANEKO et al., 2008), which indicated the good health status of these goats, and it was undisturbed and not affected by glomerular filtration. Contrary to our results, the increased total blood volume, especially in late pregnancy, induced an increase in glomerular filtration, which was also responsible for the increased values of albumin during late gestation (YOKUS et al., 2006). PICCIONE et al. (2009) reported that serum albumin increased significantly during pregnancy compared to the dioestrus period. During lactation, the lowest value of total protein was found in the late lactation period. During late lactation, total protein levels were lower than those of other periods of lactation. However, DARWESH et al. (2013) found a significant variation in total protein between week 6 (early) and week 14 (mid) of lactation in black goats. However, during early and mid-lactation, total protein plasma contents were greater than before gestation. These findings are in agreement with the results published by SADJADIAN et al. (2013) in goats. In another study (MANAT et al., 2016), total protein did not change significantly at 21 days postpartum compared to before gestation. Concerning variations in total protein between late gestation and early lactation, non-significant changes were found. In contrast, SADJADIAN et al. (2013) found that concentrations of total protein in the last weeks of pregnancy were lower than in the postpartum period. Moreover in this study, the concentration of plasma total protein did not differ significantly between pregnant and non-pregnant does. The current findings are consistent with an earlier report by WAZIRI et al. (2010), and in contrast to a report by IRIADAM (2007). In general, an increase in total protein during lactation (early and mid-lactation) compared to before gestation was shown. This reflects the increase in globulin found in this study and also found by THARWAT et al. (2013) resulting from the formation of immunoglobulin, especially during post-partum and for the high demands of milk production. There was no significant increase during these two periods compared to late gestation. AMER et al. (1999) found that not all milk proteins are formed from the breakdown of plasma proteins but all major milk proteins are formed from free amino 
acid precursors in the blood. Moreover, the values of plasma total protein in our study were in the range of values reported by BAGNIKA et al. (2014), KANEKO et al. (2008), and SADJADIAN et al. (2013).

Interestingly, urea and total protein levels increased at the end of lactation, when compared to before and late gestation, and the dry period. Urea levels peaked at the end of lactation, and decreased significantly at late gestation compared to late lactation. Nonsignificant changes were shown between early, mid and late lactation, before gestation, and late gestation. Similarly, non-significant changes were found in goats before gestation compared to late gestation (WAZIRI et al., 2010), and compared to 21 days (MANAT et al., 2016) in goats, and non-significant changes between urea in late gestation and 45 days post-partum in Akkaraman ewes (BALICKI et al., 2007). Similar to our results, urea content increased significantly at the end of lactation, compared with the dry period and before gestation (BALICKI et al., 2007). However, urea levels at the $30^{\text {th }}$ day of lactation were higher than those in the dry period in sheep (KARAPEHLIVAN et al., 2017). The increase in urea during the end of lactation could be explained by the decrease in milk formation, the reduction in glomerular filtration, as found in ewes (RODRIGUEZ et al., 1996), by the increase in protein intake (ammonia absorbed by the rumen), or finally by the increase in catabolism of amino acids. However, the decrease in urea during early, mid, and late lactation could be explained by the increase in use of amino acids in ruminants for synthesis of milk proteins, which leads to a decrease in serum urea concentration (BALICKI et al., 2007). The results indicate that Arbia goats possess high potential for conservation of nitrogen during late pregnancy and the early and mid-lactation periods.

Creatinine plasma levels were also significantly affected by the physiological stage of production, and they reached the highest and the lowest values during late pregnancy, and the dry period respectively. In general, creatinine tended to decrease during lactation, in the dry period and before gestation. Similarly, an increase in creatinine in late pregnancy compared to before pregnancy was reported in sheep (EL-SHERIF and ASSAD, 2001), while non-significant changes in this blood parameter between these two periods were seen in Sahel goats (WAZIRI et al., 2010). Contrary to our results, creatinine levels were higher in the dry period than at the end of gestation (PICCIONE et al., 2009). In the present study, we noticed that the high level of creatinine recorded in late gestation was in the normal values found by WAZIRI et al. (2010) during pregnancy. These findings suggest that the kidneys were not clinically affected and their function was well adapted to pregnancy, and there was a protein breakdown in the skeletal muscles and development of foetal musculature during late gestation (KANEKO et al., 2008). On the other hand, during the dry period, the decrease in creatinine was due to replenishment of body reserves, and regeneration of mammary tissue. 
ALT and AST are important catabolic enzymes, which play an important role in the liver function of animals. In our results, there were non-significant changes in both enzymes from before pregnancy to late gestation and early lactation. These observations were consistent with the results of WAZIRI et al. (2010) who found that the activity of both ALT and AST did not differ significantly before and in late gestation in Sahel goats. However, in comparison to before pregnancy, IRIADAM (2007) reported that plasma AST and ALT activities increased during late gestation and at 3 weeks postpartum. In contrast, SADJADIAN et al. (2013) detected significantly lower activities of AST in the plasma in preparturition goats in comparison to early lactating ones. Similarly to our results, DONIA et al. (2014) also revealed that during lactation the activities of ALT and AST were comparable with those before pregnancy. However, throughout the first week of lactation, AST and ALT were lower in Angora goats than in Anglo-Nubian, Baladi, and Damascus goats (ANWAR et al., 2012). In our study, ALT tended to increase significantly at the end of lactation, while its value was non-significant in comparison to before gestation and the dry period. Therefore, the differences in the results and values can be explained by the effect of breed and climate. Moreover, the activity of AST and ALT were within the reference range cited by KANEKO et al. (1997) in sheep and by SADJADIAN et al. (2013) in goats (for AST). The decrease in AST and ALT during lactation compared to the dry period could not be due to malnutrition since blood glucose was well maintained. The increase in AST activity in the blood of goats in the dry period indicated an increase in hepatic metabolism.

In the current study, most minerals were significantly influenced by the stages of production in Arbia goats. Plasma calcium concentrations increased significantly only during the end of lactation compared to other physiological periods studied. Similarly, ANTUNOVIC et al. (2011a) found non-significant changes between non-pregnant, pregnant and lactating ewes. During late gestation in goats, Ca levels were not significantly changed compared to before gestation (WAZIRI et al., 2010), and 3 weeks postpartum (AZAB and ABDEL-MAKSOUD, 1999), while in non-pregnant ewes the $\mathrm{Ca}$ concentration was much higher than that recorded during lactation (ANTUNOVIĆ et al., 2004). Contrary to our results, Ca levels showed significant differences between before pregnancy, late gestation, and early lactation in Kilis does (IRIADAM, 2007), and a marked decline during late pregnancy, and 3 weeks postpartum compared to before pregnancy in Baladi does (AZAB and ABDEL-MAKSOUD, 1999). The observed increase in calcium levels at the end of lactation could be attributed to the low demand for calcium for milk production approaching the dry period, or indicate an increase in intestinal absorption of calcium. Furthermore, BAGNICKA et al. (2014) also found an elevated level of $\mathrm{Ca}$ at the end of lactation in yeast treated goats. But this increase was within the reference values (KANEKO et al., 2008), and calcium levels in serum were reversely proportional to milk production (IVANOV et al., 1990). 
Lactation stages did not influence plasma concentrations of inorganic phosphorous, and non-significant changes were found between before pregnancy, pre- and postpartum by IRIADAM (2007). However, lower values for phosphorous were reported by AHMED et al. (2000) in early lactation compared to mid-lactations, and a rise after parturition by TANRITANIR et al. (2009). Non-significant variations during late pregnancy and early lactation compared to before pregnancy were also reported by AZAB and ABDELMAKSOUD (1999). In this study, Pi during late lactation increased significantly compared to before gestation, and in the dry period. But the differences were not significant between late and the end of lactation. These findings suggest that the metabolism and homeostasis of phosphorous was efficient in Arbia goats.

Interestingly, the stages of lactation also did not significantly influence $\mathrm{Na}$ and $\mathrm{K}$ plasma contents. In this study, Na did not change from late gestation to the dry period, but its level was significantly higher than that recorded in non-gestating goats. In contrast, in the study by WAZIRI et al. (2010) on Sahel goats, Na levels did not change significantly between the late and pre- gestation periods. Similarly K concentrations showed nonsignificant changes between before and late gestation (WAZIRI et al., 2010; AZAB and ABDEL-MAKSOUD, 1999). Early lactation brought an increase in both $\mathrm{Na}$ and $\mathrm{K}$ plasma levels compared to before gestation. However, $\mathrm{Na}$ and $\mathrm{K}$ concentrations did not record any significant changes between late gestation and early lactation compared to before pregnancy (AZAB and ABDEL-MAKSOUD, 1999). Similar to the findings of DAKKA and ABD EL-ALL (1992), gestating Arbia goats had higher plasma Na concentrations before gravidity. The plasma contents of $\mathrm{Na}$ and $\mathrm{K}$ during pregnancy and lactation were within the reference values (MBASSA and POULSEN, 1991; KANEKO et al., 2008).

Chloride plasma levels showed non-significant changes between all studied periods, except for a significant decrease at the end of lactation compared to early lactation, but the values for both periods showed non-significant variations in relation to the other periods, which means that the intestinal absorption of chloride during lactation is well maintained. Similarly BAGNICKA et al. (2014) found a decrease at the end of lactation as compared to early lactation in control goats, but recently, ANTUNOVIĆ et al. (2017) found no effect of the stage of lactation on chloride concentrations in the blood of Alpine goats.

Magnesium plasma content was lower before gestation compared with early, late and the end of lactation, and it showed non-significant changes between pre- and late gestation. TANRITARIN et al. (2009) also found non-significant changes for Mg between before and after parturition. Contrary, AZAB and ABDEL-MAKSOUD (1999), reported an increase of $\mathrm{Mg}$ at 4 weeks prepartum in relation to non-pregnant goats. In this study, stages of lactation did not have an effect on $\mathrm{Mg}$ concentrations, although there was a non-significant change in late gestation. It seems that Arbia goats might have decreased excretion of magnesium in urine and milk to compensate for the low availability of $\mathrm{Mg}$ 
in their forage (PUGH, 2011) if it's the case, or this results are physiological values for magnesium in Arbia goats.

According to our data, in Arbia goats, plasma Fe levels did not vary during the whole study, except for mid lactation where we measured the lowest value, which may be explained by an increase need for Fe for milk synthesis. Similar to our findings, differences in Fe levels were non-significant between late gestation and 3 weeks of lactation (AZAB and ABDEL-MAKSOUD, 1999), they decreased from the $80^{\text {th }}$ to the $140^{\text {th }}$ day of lactation in dairy goats (ANTUNOVIĆ et al., 2017), and were significantly lower in the first third of lactation in sheep (ANTUNOVIĆ et al., 2011b). Contrary to our results in previous studies on goats, Fe increased significantly after parturition compared to pregnancy (TANRITARIN et al., 2009), and declined markedly during late pregnancy, at the day of parturition and during the 3 weeks of postpartum compared to before pregnancy (AZAB and ABDEL-MAKSOUD, 1999).

\section{Conclusion}

In conclusion, the reproductive stages of Arbia goats did not have a significant effect on plasma levels of cholesterol, but the levels of the remaining blood parameters showed different significant variations. The results indicate that the physiological mechanisms of Arbia goats at 12 months old are well adapted to different physiological stages of production in a semi-arid region. Moreover, some parameters showed specificity for this breed when compared with results of other breeds of goats. Therefore, during late gestation and different periods of lactation, veterinarians and farmers need to determine the concentrations of biochemicals and minerals in the blood for better control of health and nutrition of Arbia goats, and a larger number of animals is needed to establish reference values for this breed.

\section{Acknowledgements}

This work was supported by the Algerian Ministry of Higher Education and Scientific Research (project code: D01N01UN040120140013).

\section{References}

AHMED, M. M. M., S. A. KHALID, M. E. S. BARRI (2000): Macromineral profile in the plasma of Nubian goats as affected by the physiological state. Small Rum. Res. 38, 249-254.

DOI: 10.1016/S0921-4488(00)00166-8

AMER, H. A., H. A. H. SALEM, A. A. AL-HOZAB (1999): Biochemical changes in serum and milk constituents during postpartum period in Saudi Ardy goats. Small Rum. Res. 34, 167-173. DOI: 10.1016/S0921-4488(99)00055-3 
S. A. Allaoua and D. Mahdi: Effect of physiological status on levels of blood parameters in female Arbia goats

ANTUNOVIĆ, Z., M. ŠPERANDA, Z. STEINER (2004): The influence of age and the reproductive status to the blood indicators of the ewes. Arch. Tierzucht. 47, 265-273.

DOI: 10.5194/aab-47-265-2004

ANTUNOVIC, Z., J. NOVOSELEC, H. SAUERWEIN, M. SPERANDA, M. VEGARA, V. PAVIC (2011a): Blood metabolic profile and some of hormones concentration in ewes during different physiological status. Bulgarian J. Agric. Sci. 17, 687-695.

ANTUNOVIC, Z., E. VONKO, J. NOVOSELEC, M. SPERANDA, M. VEGARA, V. PAVIĆ, B. MIOČ, M. DJIDAR (2011b): Changes in biochemical and haematological parameters and metabolic hormones in Tsigai ewes blood in the first third of lactation. Archiv Tierzucht. 54, 535-545.

ANTUNOVIĆ, Z., M. ŠPERANDA, J. NOVOSELEC, M. ĐIDARA, B. MIOČ, Ž. KLIR, D. SAMAC (2017): Blood metabolic profile and acid-base balance of dairy goats and their kids during lactation. Vet. arhiv. 87, 43-55.

ANWAR, M. M., T. A. RAMADAN, T. A. TAHA (2012): Serum metabolites, milk yield, and physiological responses during the first week after kidding in Anglo-Nubian, Angora, Baladi, and Damascus goats under subtropical conditions. J. Anim. Sci. 90, 4795-4806.

DOI: $10.2527 /$ jas.2012-5236

AZAB, M. E., H. A. ABDEL-MAKSOUD (1999): Changes in some hematological and biochemical parameters during prepartum and postpartum periods in female Baladi goats. Small Rum. Res. 34, 77-85.

DOI: $10.1016 /$ S0921-4488(99)00049-8

BAGNICKA, E., J. JARCZAK, E. A. JOZWIK (2014): Active dry yeast culture supplementation effect on the blood biochemical indicators of dairy goats. J. Adv. Dairy Res. 2, 1-7.

BALIKCI, E., A. YILDIZ, F. GURDOGAN (2007): Blood metabolite concentrations during pregnancy and post-partum in Akkaraman ewes. Small Rum. Res. 67, 247-251.

DOI: $10.1016 /$ j.smallrumres.2005.10.011

BEDO, S., E. NIKODEMUSZ, K. GUNDEL, Z. NAGY (1997) : Relations of plasma concentration of urea, glucose and total protein to milk levels of urea, lactose and protein of grazing ewes during lactation. Arch. Tierz. 40, 265-275.

CASAMASSIMA, D., M. PALAZZO, R. PIZZO (2007): Evaluation of milk production and some blood parameters in lactating autochthonous goat extensively reared in Molise region. Ital. J. Anim. Sci. 6, 615-617.

DAKKA, A. A., TH. S. ABD EL-ALL (1992): Studies on mineral picture in the blood sera of Egyptian sheep. Assiut Vet. Med. J. 28, 242-249.

DARWESH, K. A., K. Y. MERKHAN, E. T. S. BUTI (2013): Impact of lactation stage on the body condition and milk quality of Black goat. Inter. J. Agr. Food Res. 2, 48-52.

DONIA, G. R., N. H. IBRAHIM, Y. M. SHAKER, F. M. YOUNIS, H. Z. AMER (2014): Liver and kidney functions and blood minerals of shami goats fed salt tolerant plants under the arid conditions of southern Sinai. Egypt J. American Sci. 10, 1-11. 
S. A. Allaoua and D. Mahdi: Effect of physiological status on levels of blood parameters in female Arbia goats

EL-SHERIF, M. M. A., F. ASSAD (2001): Changes in some blood constituents of Barki ewes during pregnancy and lactation under semi arid conditions. Small Rum. Res. 40, 269-277.

DOI: 10.1016/S0921-4488(01)00174-2

FAO (2017): Food and Agriculture Organisation of the United Nations. Production livestock_E_ all_data (normalized).zip. Excel file. http://www.fao.org/faostat/en/" \l "home.

GRUM, D. E., J. K. DRACKLY, R. S. YOUNKER, D. W. LACOUNT, J. J. VEENHUIZEN (1996): Nutrition during the dry period and hepatic lipid metabolism of periparturient dairy cows. J. Dairy Sci. 79, 1850-1864.

DOI: $10.3168 /$ jds.S0022-0302(96)76553-0

HELMUT, K. M., F. GREGOR (2012): Physicochemical characteristics of goats milk in Austriaseasonal variations and differences between six breeds. Dairy Sci. Technol. 92, 167-177.

DOI: $10.1007 / \mathrm{s} 13594-011-0047-0$

IRIADAM, M. (2007): Variation in certain haematological and biochemical parameters during the peri-partum period in Kilis does. Small Rum. Res. 73, 54-57.

DOI: 10.1016/j.smallrumres.2006.11.001

IVANOV, I., M. J. RAJIČ, M. JOVANOVIČ, M. LALIĆ (1990): Concentration of calcium in the blood serum in high-pregnant and lactating cows in intensive breeding. Vet. Glasnik. 44, 359-364.

KANEKO, J. J. (1997): Clinical Biochemistry of Domestic Animals, $5^{\text {th }}$ ed., Academic Press, San Diego, pp. 890-894.

KANEKO, J. J., J. W. HARVEY, M. L. BRUSS (2008): Clinical biochemistry of Domestic Animals. $6^{\text {th }}$ ed., Academic Press, Inc., San Diego, London, Boston, New York, Sydney, Tokyo, Toronto, pp. 882-888.

KARAPEHLIVAN, M., E. ATAKISI, O. R. ATAKISI, S. M. YUCAYURT PANCARCI (2007): Blood biochemical parameters during the lactation and dry period in Tuj ewes. Small Rum. Res.73, 267-271.

DOI: 10.1016/j.smallrumres.2006.12.006

MANAT, T. D., S. S. CHAUDhARY, V. K. SINGH, S. B. PATEL, G. PURI (2016): Hematobiochemical profile in Surti goats during post-partum period. Vet. World. 9, 19-24. DOI: 10.14202/vetworld.2016.19-24

MOUSTARIA, A. (2008): Identification of goat breeds of dry areas in Algeria. In: Rev. Régions Arides. 21, 1378-1382 (in French).

NAZIFI, S., M. SAEB, S. M. GHAVAMI (2002): Serum lipid profile in Iranian fat-tailed sheep in late pregnancy, at parturition and during the post-parturition period. J. Vet. Med. 49, 9-12.

DOI: 10.1046/j.1439-0442.2002.00405.x

PARK, Y. W., M. JUAREZ, M. RAMOS, G. F. W. HAENLEIN (2007): Physico-chemical characteristics of goat and sheep milk. Small Rum. Res. 68, 88-113.

DOI: 10.1016/j.smallrumres.2006.09.013

Vet. arhiv 88 (5), 643-660, 2018 
S. A. Allaoua and D. Mahdi: Effect of physiological status on levels of blood parameters in female Arbia goats

PARK, Y. W. (2012): Goat milk and human nutrition. Proceedings of the $1^{\text {st }}$ Asia Dairy Goat Conference, 9-12 April, Kuala Lumpur, Malaysia, pp. 31-38.

PICCIONE, G., C. GIOVANNI, G. CLAUdiA, G. FORTUNATA, C. SEBASTIANO, P. P. ZUMBO (2009): Selected biochemical serum parameters in ewes during pregnancy, postparturition, lactation and dry period. Anim. Sci. Pap. Rep. 27, 321-330.

PICCIONE, G., V. MESSINA, C. GIANNETTO, S. CASELlA, A. ASSENZA, F. FAZIO (2011): Seasonal variations of the serum proteins in sheep and goats. Arch. Tierzucht. 54, 399-405.

PICCIONE, G., V. MESSINA, I. VAZZANA, S. DARA, C. GIANETTO, A. ASSENZA (2012): Seasonal variations of some serum electrolyte concentrations in sheep and goats, Comp. Clin. Pathol. 21, 911-915.

DOI: $10.1007 / \mathrm{s} 00580-011-1198-3$

PUGH, D. G. (2011): Nutritional Requirements of Goats. MSD Veterinary Manual. Merck \& Co., Inc., Kenilworth, NJ, USA.

RIBEIROA, N. L., R. G. COSTA, E. C. PIMENTA FILHO, M. N. RIBEIROB, A. CROVETTIB, E. P. SARAIVA, R. BOZZI (2016): Adaptive profile of Garfagnina goat breed assessed through physiological, haematological, biochemical and hormonal parameters Small Rum. Res. 144, 236-241.

RODRIGUEZ, M. N., I. TEBOT, A. LE BAS, C. NIEVAS, L. LENG, A. CIRIO (1996): Renal functions and urea handling in pregnant and lactating Corriedale ewes. Can. J. Anim. Sci. 76, 469-472.

DOI: $10.4141 /$ cjas96-070

SADJADIAN, R., H. A. SEIFI, M. MOHRI, A. A. NASERIAN, N. FARZANEH (2013): Variations of energy biochemical metabolites in periparturient dairy Saanen goats. Comp. Clin. Pathol. 22, 449-456.

DOI: $10.1007 / \mathrm{s} 00580-012-1431-8$

SKOTNICKA, E., Z. MUSZCZYŃSKI, M. SUSKA (2011): Effect of the periparturient period on serum lipid and cholesterol lipoprotein concentrations in goats (Capra hircus). Acta Vet. Hung. 59, 445-454.

DOI: $10.1556 /$ AVet.2011.032

TANRITANIR, P., S. DEDE, E. CEYLAN (2009): Changes in some macro mineral and biochemical parameters in female healthy Siirt Hair goats before and after parturition. J. Anim. Vet. Adv. 8, 530-533.

THARWAT, M., A. ALI, F. AL-SOBAYIL (2013): Hematological and biochemical profiles in goats during the transition period. Comp. Clin. Pathol. 24, 1-7.

DOI: $10.1007 / \mathrm{s} 00580-013-1842-1$

TOMOVIĆ, V. M., M. R. JOKANOVIĆ, J. V. ŠVARC-GAJIĆ, I. M. VASILJEVIĆ, B. V. ŠOJIĆ, S. B. ŠKALJAC, I. I. PIHLER, V. B. SIMIN, M. M. KRAJINOVIĆ, M. M. ŽUJOVIĆ (2016): Physical characteristics and proximate and mineral composition of Saanen 
S. A. Allaoua and D. Mahdi: Effect of physiological status on levels of blood parameters in female Arbia goats

goat male kids meat from Vojvodina (Northern Serbia) as influenced by muscle. Small Rum. Res. 145, 44-52.

DOI: $10.1016 /$ j.smallrumres.2016.10.019

WANG-SHENG, Z., H. SHI-LIANG, Y. KANG, W. HUI, W. WEI, L. JUAN, L. JUN (2014): Lipoprotein lipase, tissue expression and effects on genes related to fatty acid synthesis in goat mammary epithelial cells. Int. J. Mol. Sci. 15, 22757-22771.

DOI: $10.3390 /$ ijms 151222757

WAZIRI, M. A., A. Y. RIBADU, N. SIVACHELVAN (2010): Changes in the serum proteins, haematological profile and some serum biochemical in the gestation period in the Sahel goats. Vet. arhiv 80, 215-224.

WEBB, E. C., N. H. CASEY, L. SIMELA (2005): Goat meat quality. Small Rum. Res. 60, 153166.

DOI: 10.1016/j.smallrumres.2005.06.009

YOKUS, B., D. U. CAKIR, Z. KANAY, T. GULTEN, E. UYSAL (2006): Effects of seasonal and physiological variations on the serum chemistry, vitamins and thyroid hormone concentrations in sheep. J. Vet. Med. 53, 271-276.

DOI: $10.1111 /$ j.1439-0442.2006.00831.x

Received: 23 August 2017

Accepted: 21 April 2018

\section{ALLAOUA, S. A., D. MAHDI: Biokemijski pokazatelji plazme i minerala tijekom različitih faza proizvodnje koza arbia iz stepskog područja sjeveroistočnog Alžira. Vet. arhiv 88, 643-660, 2018.}

\section{SAŽETAK}

Cilj rada bio je istražiti varijacije u koncentraciji krvnih pokazatelja tijekom različitih faza proizvodnje tradicionalno uzgajane koze arbia iz stepskog područja sjeveroistočnog Alžira. Deset koza (u dobi $12 \pm 0$ mjeseci) odabrano je s jedne farme. Krv je prikupljana jednom od svake koze prije gravidnosti, zatim $6,87 \pm 4,61$ dana prije jarenja (kasna gravidnost) te u 3. (rana laktacija), 8. (srednja laktacija), 12. (kasna laktacija) i 16. (kraj laktacije) tjednu laktacije. Posljednji uzorci krvi uzeti su tijekom drugog tjedna nakon zasušenja. U uzorcima su utvrđivani trigliceridi (TG), ukupni proteini (TP), albumini (Alb), globulini (Glb), alanin-aminotransferaza (ALT), aspartat-aminotransferaza (AST), glukoza u plazmi (Glu), kolesterol (Chol), Ca, Pi, Fe, Mg, Na, K i Cl. Razina kolesterola u plazmi koza arbia nije bila pod signifikantnim utjecajem proizvodnog razdoblja. Tijekom kasnoe gravidnosti zabilježene su najviše razine triglicerida i kreatinina. U kasnoj laktaciji, u odnosu na kasnu gravidnost, bili su povećani ureja i kalij, a aktivnost AST-a znatno se smanjila. Glukoza, albumini, ukupni proteini i ureja signifikantno su porasli tijekom kasne laktacije, a željezo se povećalo tijekom srednje laktacije. Sagledavajući cijelu laktaciju, razine Pi, Mg, $\mathrm{Na}$ i K u plazmi se nisu mijenjale, glukoza i Fe signifikantno su smanjeni sredinom laktacije, trigliceridi su sniženi, a kreatinin je povećan u ranoj laktaciji. Aktivnost ukupnih proteina, globulina i AST-a smanjena je u kasnoj laktaciji, dok su se ALT, ureja, i Ca povećali, a Cl se snizio tijekom završne laktacije. U usporedbi s razdobljem zasušenja, glukoza, albumini, ALT, AST, Na i K smanjili su se, a kreatinin i globulini signifikantno su se povećali prije gravidnosti. Ukupni proteini i kreatin signifikantno 
S. A. Allaoua and D. Mahdi: Effect of physiological status on levels of blood parameters in female Arbia goats

su povećani, a aktivnost albumina i AST-a signifikantno je smanjena tijekom kasne gravidnosti. Zaključno, za bolju kontrolu zdravlja i hranidbe koza arbia nužno je određivati pokazatelje u krvi.

Ključne riječi: pokazatelji u krvnoj plazmi; fiziološke faze proizvodnje; koze arbia; stepa; Alžir 